\title{
SOIL WATER RETENTION CURVE AND S INDEX AS SOIL PHYSICAL QUALITY INDICATORS FOR INTEGRATED PRODUCTION SYSTEMS
}

\author{
Wellington de A. Magalhães ${ }^{1 *}$, Onã da S. Freddi², Flávio J. Wruck ${ }^{3}$, Fabiano A. Petter², \\ Renan F. R. Tavanti ${ }^{4}$
}

1*Corresponding author. Universidade Federal de Mato Grosso/ Cuiabá - MT, Brasil. E-mail: wellingtonagro@gmail.com

\section{KEYWORDS}

Eucalyptus, pore size distribution, soil structure, ICLF.

\begin{abstract}
Assess the physical quality of agricultural soils it is important to establish the management more adequate for plant growth. In this study, the soil water retention curve and $\mathrm{S}$ index as indicators of soil physical quality were evaluated in five integrated production systems in the following forestry arrangements: Eucalyptus in a single line, double line and triple line (Eucalyptus I, II and III respectively), Balsa in triple line and Teak triple line. The density and arrangement of forest trees influence the soil physical properties. Less soil water retention was observed in the Teak and Balsa wood systems in the layers $0-0.10$ and $0.10-0.20 \mathrm{~m}$. The field capacity, permanent wilting point, and available water were lower under the projection from the treetops, providing less soil water retention at this site. This position suffers more influence of the animal's footstep, having greater alterations on the soil structure. Integrated production systems showed poor soil structural quality based on the $S$ index, averaging 0.034 and 0.035 for layers 0 0.10 and $0.10-0.20 \mathrm{~m}$ respectively.
\end{abstract}

\section{INTRODUCTION}

Agricultural systems are in constant transformation, in the aim of better productivities and few impacts on the environment. One of the most innovating systems developed in the last decades is, the integrated systems, associated with no tillage system (Balbino et al., 2011). Those systems improve soil quality and increase productivity in a sustainable way. In function of the needs of determined regions, some properties started to introduce forestry species in agriculture and cattle systems. These systems are called Crop-LivestockForestry Integration (ICLF) (Pacheco et al., 2013).

According to Barcellos et al. (2011), ICLF consists in the management of cattle, agricultural and forestry production systems in the same area. In this system, the crop could be inserted only in the installation process of the ICLF system, or throughout the years (Balbino et al., 2012). Meanwhile, little is known about the correct management of these systems and the implications on the soils physical quality, as a function of the forestry arrangements. Souza-Neto et al. (2014) mentioned that greater forestry densities in ICLF resulted in greater soil compaction, which provides less physical protection. Because of the shadow of the treetops, the production of grains can also be influenced, where the determining factor is the arrangement of forestry species (Souza-Neto et al., 2014; Mendes et al., 2013; Santos et al., 2015). Carvalho et al. (2004) evaluated the physical attributes of a Latosol in an agroforestry system and observed less soil density, greater soil porosity and less soil resistance to penetration in these systems when compared with conventional systems.

The soil water retention curve (SWRC) represents the relationship between the energy in which water is been retain and the corresponding water content (van Genuchten, 1980). It has been widely used in studies of soil physical quality, because, the tension and the volume of soil water retained depends on its structure. That way, the SWRC is a reflex of the pores distribution by size, where, each applied tension drains out a specific pore size (Paixão et al., 2009). Lepsch (2011) mentioned that the content of water retained at a specific tension is a specific characteristic for each soil, because of a number of actuating factors. According to Machado et al. (2008), the water retention curve could directly affect the

\footnotetext{
${ }^{2}$ Universidade Federal de Mato Grosso/ Sinop - MT, Brasil.

${ }^{3}$ Embrapa Agrossilvipastoril/ Sinop - MT, Brasil.

${ }^{4}$ Universidade Estadual Paulista "Júlio Mesquita Filho"/ Ilha Solteira - SP, Brasil.

Received in: 3-24-2017

Accepted in: 10-28-2017
} 
management and practices that should be used in agricultural systems.

From the SWRC it is possible to determine the $\mathrm{S}$ index, developed by Dexter (2004a, 2004b, 2004c), that has been utilized as an indicator of the soils physical quality (Rosseti et al., 2013; Lima et al., 2014; Melo Filho et al., 2015). This indicator is based on the inflection point of the SWRC model proposed by van Genuchten (1980), having its values highly correlated with soil density, total porosity, macroporosity, and soil organic matter (Dexter, 2004a; Andrade \& Stone, 2008; Silva et al., 2012; Cunha et al., 2011). There is still no consensus about the restrictive values for Brazilian soils. Dexter (2004a) proposed that $S$ index values should be higher than 0.035 for areas with favorable conditions and $<0.020$ values for conditions very restrictive for plant growth and development in temperate areas. Andrade \& Stone (2008), evaluating Cerrado soils, suggested the limit value of the $\mathrm{S}$ index as 0.045 as adequate for differentiating good soils structural quality.

The ICLF are widely spreading all throughout the Brazilian territory, mainly because of the advantage related to the production of each isolated component. Considering them as complex systems, and modifying the relationships between the factors that determine productivity, this is the reason why there are very different results when compared with isolated productive systems. In the northern region of Mato Grosso, there are few studies about the physical quality of the ICLF systems, which are necessary due to the importance of these properties in soil sustainable management.

Considering the number of forest trees and their arrangement between annual and perennial crops in Crop-
Livestock- Forestry Integration systems, we supposed that there are contributions to changes in the soil physics attributes. Therefore, the objective of this study was to evaluate the soil water retention curve and $S$ index of a Yellow Red Latosol, as indicators of soil physical quality in different Crop-Livestock- Forestry Integration systems after four years of establishment.

\section{MATERIAL AND METHODS}

The study was developed in the Technological Reference Unit (TRU) of Brazilian Agricultural Research Corporation (Embrapa Agrossilvipastoril), located in the Fazenda Gamada, in Nova Canaã do Norte, Mato Grosso, Brazil (10²4'10' S and 55'43'22' W). The mean altitude is 280 meters, and according to Köppen classification, the region has an Awi climate (tropical wet) with a marked dry season. The soil classification according to the SiBCS (Santos et al., 2013) was Dystrophic Red-Yellow Latosol (DRYL), corresponding to Ferralsols according to FAO (WRB, 2014), shows a granulometric composition in the $0-0.20 \mathrm{~m}$ depth layer of $440 \pm 1.74 \mathrm{~g} \mathrm{~kg}^{-1}$ of clay, $144 \pm$ $2.01 \mathrm{~g} \mathrm{~kg}^{-1}$ of silt and $416 \pm 2.89 \mathrm{~g} \mathrm{~kg}^{-1}$ of sand.

The studied area was deforested in 1998 for the establishment of two years of pastures, using Urochloa brizantha. Afterwards, the land was used to grow annual species during six consecutive years (two years with rice (Oryza sativa) and four with soybean (Glycine max)/maize (Zea mays) rotation). After this period, the crops were substituted for two more years of pastures, which stayed until the establishment of the integrated systems (Oliveira et al., 2015) (Table 1).

TABLE 1. Crop history in the experimental area of Nova Canaã do Norte-MT, Brazil.

\begin{tabular}{|c|c|c|c|c|c|}
\hline $\begin{array}{c}\text { Agricultural } \\
\text { year }\end{array}$ & Eucalyptus I & Eucalyptus II & Eucalyptus III & Teak & Balsa wood \\
\hline 1998 & $\begin{array}{l}\text { Opening } \\
\text { the area }\end{array}$ & $\begin{array}{l}\text { Opening } \\
\text { the area }\end{array}$ & $\begin{array}{l}\text { Opening } \\
\text { the área }\end{array}$ & $\begin{array}{l}\text { Opening } \\
\text { the area }\end{array}$ & $\begin{array}{l}\text { Opening } \\
\text { the area }\end{array}$ \\
\hline $\begin{array}{l}1998 / 1999 \\
1999 / 2000 \\
\end{array}$ & Urochloa brizantha & Urochloa brizantha & Urochloa brizantha & Urochloa brizantha & Urochloa brizantha \\
\hline $\begin{array}{l}2000 / 2001 \\
2001 / 2002 \\
\end{array}$ & $\begin{array}{l}\text { Glycine max }+ \\
\text { Zea mays }\end{array}$ & $\begin{array}{l}\text { Glycine max }+ \\
\text { Zea mays }\end{array}$ & $\begin{array}{l}\text { Glycine max }+ \\
\text { Zea mays }\end{array}$ & $\begin{array}{l}\text { Glycine max }+ \\
\text { Zea mays }\end{array}$ & $\begin{array}{l}\text { Glycine max }+ \\
\text { Zea mays }\end{array}$ \\
\hline $\begin{array}{l}2002 / 2003 \\
2003 / 2004 \\
2004 / 2005 \\
2005 / 2006\end{array}$ & $\begin{array}{l}\text { Upland rice } \\
\text { Oryza sativa }\end{array}$ & $\begin{array}{l}\text { Upland rice } \\
\text { Oryza sativa }\end{array}$ & $\begin{array}{l}\text { Upland rice } \\
\text { Oryza sativa }\end{array}$ & $\begin{array}{l}\text { Upland rice } \\
\text { Oryza sativa }\end{array}$ & $\begin{array}{l}\text { Upland rice } \\
\text { Oryza sativa }\end{array}$ \\
\hline $\begin{array}{l}2005 / 2006 \\
2007 / 2008 \\
2008 / 2009\end{array}$ & $\begin{array}{l}\text { Pasture } \\
\text { U. brizantha }\end{array}$ & $\begin{array}{l}\text { Pasture } \\
\text { U. brizantha }\end{array}$ & $\begin{array}{c}\text { Pasture } \\
\text { U. brizantha }\end{array}$ & $\begin{array}{l}\text { Pasture } \\
\text { U. brizantha }\end{array}$ & $\begin{array}{l}\text { Pasture } \\
\text { U. brizantha }\end{array}$ \\
\hline $2008 / 2009$ & $\begin{array}{c}\text { Eucalyptus I } \\
+O . \text { sativa }+U . \\
\text { brizantha } \\
\end{array}$ & $\begin{array}{c}\text { Eucalyptus II } \\
+O . \text { sativa }+U . \\
\text { brizantha } \\
\end{array}$ & $\begin{array}{c}\text { Eucalyptus III } \\
+O . \text { sativa }+U . \\
\text { brizantha } \\
\end{array}$ & $\begin{array}{l}\text { Teak }+O . \text { sativa }+ \\
\quad U . \text { brizantha }\end{array}$ & $\begin{array}{c}\text { Balsa wood }+O . \text { sativa }+ \\
U . \text { Brizantha }\end{array}$ \\
\hline $\begin{array}{l}2009 / 2010 \\
2010 / 2011\end{array}$ & $\begin{array}{l}\text { Eucalyptus I } \\
+ \text { G. max / Z. mays } \\
+ \text { U. brizantha } \\
\end{array}$ & $\begin{array}{l}\text { Eucalyptus II } \\
+ \text { G. max / Z. mays } \\
+ \text { U. brizantha } \\
\end{array}$ & $\begin{array}{c}\text { Eucalyptus III } \\
+ \text { G. max / Z. mays } \\
+ \text { U. brizantha }\end{array}$ & $\begin{array}{l}\text { Teak }+G . \text { max } / Z . \\
\text { mays }+U . \text { brizantha }\end{array}$ & $\begin{array}{c}\text { Balsa wood }+G . \text { max } / Z \\
\text { mays }+U . \text { brizantha }\end{array}$ \\
\hline $\begin{array}{l}2011 / 2012 \\
2012 / 2013\end{array}$ & $\begin{array}{c}\text { Eucalyptus I } \\
+U . \text { brizantha }\end{array}$ & $\begin{array}{c}\text { Eucalyptus II } \\
+U . \text { brizantha }\end{array}$ & $\begin{array}{l}\text { Eucalyptus III } \\
+ \text { U. brizantha }\end{array}$ & Teak $+U$. brizantha & $\begin{array}{l}\text { Balsa wood }+U . \\
\text { Brizantha }\end{array}$ \\
\hline
\end{tabular}

In January 2009, the area was cleaned using glyphosate ( $1.26 \mathrm{~kg} \mathrm{ha}^{-1}$ of ative ingredient) and then, was held opening furrows for the planting of forest species, left $20 \mathrm{~m}$ between lines, space used for crops and cattle (Assis et al., 2015). The treatments consisted in CropLivestock- Forestry Integration (ICLF) with different 
arrangements and planting densities: Eucalyptus (Eucalyptus urograndis) in simple line with $2 \mathrm{~m}$ between trees and $20 \mathrm{~m}$ between rows (250 trees $\left.\mathrm{ha}^{-1}\right)$; Eucalyptus in double line with $3 \mathrm{~m} \times 2 \mathrm{~m}$ between trees and $20 \mathrm{~m}$ between rows (434 trees $\mathrm{ha}^{-1}$ ); and Eucalyptus in triple line, with $3 \mathrm{~m} \times 3 \mathrm{~m} \times 2 \mathrm{~m}$ between rows and 20 meters between rows $\left(577\right.$ trees $\left.\mathrm{ha}^{-1}\right)$. The remaining treatments correspond to Teak (Tectona grandis L.f.) and Balsa wood (Ochoroma pyramidale), both in triple line $3 \mathrm{~m} \mathrm{x} 3 \mathrm{~m} \times 2$ $\mathrm{m}$ between rows and 20 meters between rows $(577$ trees $\left.\mathrm{ha}^{-1}\right)$. All of the treatments were planted from east to west to allow more penetration of solar irradiance between lines.

The space between rows $(20 \mathrm{~m})$ was used for crops in the beginning of the experiment. In January 2009, riceUrochloa rotation system was established, using the forage a cover crop. In the harvest of 2009/2010 at the first harvest, soybean was planted, followed rice in the second harvest. In the harvest 2010/2011, it was established a soybean-maize rotation. In March 2011, pasture was introduced in the middle of maize line and began to be grazed in July 2011. The average stoke rate per area was of 3.7 animals $\mathrm{ha}^{-1}$ in the growing and finishing phases.

With the purpose of evaluating the variability of soils physical properties under different environments provided by the difference between the ICLF and the rotation of the animals, it was considered five positions of sampling sites in each system. The site positions were established in a transversal way to the rows of forestry species. The distance between the trees and the point of sampling were, $\mathrm{P} 1: 10 \mathrm{~m}$ and $\mathrm{P} 2: 5 \mathrm{~m}$ from the trees at the west direction, P3: under the treetops, P4: $5 \mathrm{~m}$ and P5: 10 $\mathrm{m}$ from the trees at east direction.

In May 2013, soil undisturbed samples were collected in each site in the layers $0-0.10 \mathrm{~m}$ and $0.10-0.20$ $m$ soil depth, with three repetitions in each ICLF, resulting in 150 samples. The samples were collected with a metallic cylinder of $0.049 \mathrm{~m}$ diameter and $0.05 \mathrm{~m}$ height.

The undisturbed samples were saturated by gradual water sheet elevation during 24 hours, then, subjected to pressures $(\Psi)$ of $-0.001,-0.003,-0.006,-0.008$ and -0.01 $\mathrm{MPa}$, in a pressure table, after were transferred to a Richard's chamber to be subjected to pressures of -0.03 , $0.06,-0.1,-0.3$ and $-0.5 \mathrm{MPa}$. For the determination at 1.5 MPa deformed samples were utilized in the Richard's chamber. When equilibrium was reached, water content determinations were made according to Klein (2014). After the determination of water content, the samples were oven dried at $105^{\circ} \mathrm{C}$ for 48 hours.

The soil water retention curve (SWRC) adjustments were made following the model proposed by van Genuchten (1980), having as restrictive, $m=1-1 / n$ (equation 1), minimizing the sum of the square deviations, using SWRC software (Dourado Neto et al., 2001). That way obtaining the empiric parameters of adjustment, $\alpha, \mathrm{m}$ and $n$, and fixating $\Theta$ s (saturation water content) at the value correspondent to the total porosity.

$$
\theta=\theta r+\frac{\Theta s-\theta r}{\left[1+\left(\alpha\left|\Psi_{m}\right|\right)^{n}\right]^{1-\frac{1}{n}}}
$$

where,

$\Theta:$ volumetric water content $\left(\mathrm{m}^{3} \mathrm{~m}^{-3}\right)$;
Or: residual water content $\left(\mathrm{m}^{3} \mathrm{~m}^{-3}\right)$;

Өs: saturation water content $\left(\mathrm{m}^{3} \mathrm{~m}^{-3}\right)$;

$\Psi$ : matric potential $(\mathrm{MPa})$ and $\alpha(\mathrm{MPa})$, and

$\alpha, \mathrm{n}, \mathrm{m}$ : empiric parameters of the equation.

From the SWRC was obtained the available water content (AWC), calculated from the difference between $\Theta$ from $\Psi$, equivalent to the field capacity (FC): $-0.01 \mathrm{MPa}$ and wilting point (WP): $-1.5 \mathrm{MPa}$.

The $\mathrm{S}$ index was determined using as a base the previously obtained parameters and from the declivity formed at the inflection point of the SWRC (Dexter, 2004c), using the [eq. (2)].

$$
s=-n(\Theta s-\Theta r)\left[1+\frac{1}{m}\right]^{-(1+m)}
$$

where,

$\mathrm{n}$ and $\mathrm{m}$ are the empiric parameters that determine the shape of the curve;

$\Theta s$ is the saturation water content $\left(\mathrm{kg}^{1} \mathrm{~kg}^{-1}\right)$, and

$\Theta r$ is the residual water content $\left(\mathrm{kg}^{1} \mathrm{~kg}^{-1}\right)$.

The pore distribution curves were obtained from the coefficients of the van Genuchten function, by obtaining the derivate $(\mathrm{d} \Theta / \mathrm{d} \Psi)$ of the equations related to $\Psi$ (Libardi, 2010; Fidalski et al., 2013).

The treatments were separated using the bootstrap technique, with 1000 random resamplings with reposition, according to the method described by Christie (2004). This technique allows the estimation of parameters such as the average, variance, and confidence interval, among others. It is called non-parametric "bootstrap", since bootstrap estimates are based on data, only; therefore, the probability distribution for these data is not expected (Melo Filho et al., 2002; Efron \& Tibshirani, 1993). Based on the universe of 1000 values, it was also possible to set the upper and lower limits of the confidence interval of the mean at $95 \%$ probability. This procedure was useful for further comparison between means (Mello et al., 2015). Thus, means presenting common values within their confidence intervals, where the error bars overlap, did not differ from each other; whereas the absence of common values indicated significant difference (at 5\% probability) between them.

\section{RESULTS AND DISCUSSION}

There was similarity of the $\mathrm{n}$ coefficient between all Crop-Livestock- Forestry Integration (ICLF) systems in the $0-0.10 \mathrm{~m}$ layer (Table 2) and between sampling positions in both layers (Table 3). The mean values for $n$ were 1.329 and 1.324 for the layers $0-0.10$ and $0.10-0.20$ $\mathrm{m}$, respectively. The $\mathrm{n}$ coefficient corresponds to the pore size distribution index and together with the alpha parameter $(\alpha)$ affects the shape of the SWRC. These coefficient values were above the values found by Machado et al. (2008) and Fidalski et al. (2013), indicating a higher potential of water retention in the soil with integrated systems due to the distribution of soil pores sizes from small to large (van Genuchten \& Nielsen, 1985). 
TABLE 2. Mean values for the coefficients of van Genuchten equation $(\Theta r, \Theta s, n$, and $\alpha)$ and the physical properties of Yellow Red Latosol subjected to integrated production systems.

\begin{tabular}{|c|c|c|c|c|c|}
\hline \multirow{2}{*}{$\begin{array}{c}\text { Layer } \\
\text { m }\end{array}$} & \multirow{2}{*}{ ICLF } & \multicolumn{4}{|c|}{ Retention Curve Coefficients ${ }^{(1)}$} \\
\hline & & $\theta \mathrm{r}$ & $\theta s$ & $\mathrm{n}$ & $\alpha$ \\
\hline \multirow{5}{*}{$0-0.10$} & Eucalyptus I & $0.22 \mathrm{a}$ & $0.48 \mathrm{a}$ & $1.29 \mathrm{a}$ & $0.045 \mathrm{a}$ \\
\hline & Eucalyptus II & $0.24 \mathrm{a}$ & $0.49 \mathrm{a}$ & $1.33 \mathrm{a}$ & $0.034 \mathrm{ab}$ \\
\hline & Eucalyptus III & $0.24 \mathrm{a}$ & $0.49 \mathrm{a}$ & $1.35 \mathrm{a}$ & $0.037 \mathrm{ab}$ \\
\hline & Teak & $0.22 \mathrm{a}$ & $0.45 \mathrm{~b}$ & $1.33 \mathrm{a}$ & $0.024 \mathrm{~b}$ \\
\hline & Balsa Wood & $0.18 \mathrm{~b}$ & $0.45 \mathrm{~b}$ & $1.35 \mathrm{a}$ & $0.030 \mathrm{~b}$ \\
\hline \multirow{5}{*}{$0.10-0.20$} & Eucalyptus I & $0.24 \mathrm{a}$ & $0.48 \mathrm{a}$ & $1.34 \mathrm{ab}$ & $0.106 \mathrm{a}$ \\
\hline & Eucalyptus II & $0.24 \mathrm{a}$ & $0.48 \mathrm{a}$ & $1.30 \mathrm{~b}$ & $0.083 \mathrm{ab}$ \\
\hline & Eucalyptus III & $0.24 \mathrm{a}$ & $0.49 \mathrm{a}$ & $1.36 \mathrm{a}$ & $0.091 \mathrm{ab}$ \\
\hline & Teak & $0.22 \mathrm{~b}$ & $0.45 \mathrm{~b}$ & $1.31 \mathrm{ab}$ & $0.076 \mathrm{ab}$ \\
\hline & Balsa Wood & $0.18 \mathrm{c}$ & $0.44 \mathrm{~b}$ & $1.31 \mathrm{~b}$ & $0.059 \mathrm{~b}$ \\
\hline
\end{tabular}

$\alpha \mathrm{n}$ : coefficients for determining soil water retention curve.

The bootstrap analysis indicated difference for the alpha coefficient and for $\Theta s$, Or among the Eucalyptus I, II and III, Teak and Balsa systems in the 0-0.10 and 0.10$0.20 \mathrm{~m}$ layers (Table 2). No significant differences were observed between the coefficients $\Theta$ s and $\Theta r$ among the soil sampling positions, in both layers analyzed, according to Table 3.

Differences were showed in the ICLF alpha coefficient of the SWRC in the $0-0.10 \mathrm{~m}$ soil depth, where
Eucalyptus I expressed the highest value (Table 2; Figure $1)$. The alpha coefficient corresponds to the inverse value of the entry of air in the soil $\left(\mathrm{hPa}^{-1}\right)$, meaning that at the beginning of the drainage process in the soil, it will occur a faster entry of air in the soil pores in the Eucalyptus systems (van Genuchten, 1980). In relation to the sampling position, there was a difference only for the alpha coefficient in the $0-0.10 \mathrm{~m}$ layer, with the higher value in the Eucalypt III system (Table 3).

TABLE 3. Mean values for the coefficients of van Genuchten equation ( $\Theta r, \Theta s, n$, and $\alpha$ ) of the retention curve of a Yellow Red Latosol subjected to integrated systems production in the $0-0.10$ and $0.10-0.20 \mathrm{~m}$ layer.

\begin{tabular}{|c|c|c|c|c|c|}
\hline \multirow{2}{*}{$\begin{array}{c}\text { Layer } \\
\text { m }\end{array}$} & \multirow{2}{*}{ Sampling position } & \multicolumn{4}{|c|}{ Retention Curve Coefficients ${ }^{(1)}$} \\
\hline & & Өr & Os & $\mathrm{n}$ & $\alpha$ \\
\hline \multirow{5}{*}{$0-0.10$} & 1 & $0.22 \mathrm{a}$ & $0.48 \mathrm{a}$ & $1.33 \mathrm{a}$ & $0.033 \mathrm{~b}$ \\
\hline & 2 & $0.22 \mathrm{a}$ & $0.47 \mathrm{a}$ & $1.34 \mathrm{a}$ & $0.019 \mathrm{c}$ \\
\hline & 3 & $0.22 \mathrm{a}$ & $0.48 \mathrm{a}$ & $1.31 \mathrm{a}$ & $0.054 \mathrm{a}$ \\
\hline & 4 & $0.22 \mathrm{a}$ & $0.46 \mathrm{a}$ & $1.34 \mathrm{a}$ & $0.033 \mathrm{~b}$ \\
\hline & 5 & $0.23 \mathrm{a}$ & $0.46 \mathrm{a}$ & $1.34 \mathrm{a}$ & $0.030 \mathrm{bc}$ \\
\hline \multirow{5}{*}{$0.10-0.20$} & 1 & $0.23 \mathrm{a}$ & $0.46 \mathrm{a}$ & $1.33 \mathrm{a}$ & $0.066 \mathrm{a}$ \\
\hline & 2 & $0.22 \mathrm{a}$ & $0.48 \mathrm{a}$ & $1.32 \mathrm{a}$ & $0.094 \mathrm{a}$ \\
\hline & 3 & $0.23 \mathrm{a}$ & $0.47 \mathrm{a}$ & $1.32 \mathrm{a}$ & $0.102 \mathrm{a}$ \\
\hline & 4 & $0.22 \mathrm{a}$ & $0.47 \mathrm{a}$ & $1.32 \mathrm{a}$ & $0.080 \mathrm{a}$ \\
\hline & 5 & $0.23 \mathrm{a}$ & $0.46 \mathrm{a}$ & $1.34 \mathrm{a}$ & $0.072 \mathrm{a}$ \\
\hline
\end{tabular}

$\alpha \mathrm{n}$ : coefficients for determining soil water retention curve.

The van Genuchten (1980) equation explains more than $97 \%$ of the soil water retention $\left(\mathrm{R}^{2}>0.97\right)$, with $\mathrm{F}$ values highly significant $(\mathrm{p}<0.01)$ for all the samples. The coefficients $\Theta \mathrm{s}, \Theta \mathrm{r}, \alpha$, and $\mathrm{n}$ were statistically significant, not showing null values in theirs trust limits. The SWRC were different in each integrated system, in $0-0.10$ and 0.10-0.20 m soil depth (Figure 1).

The SWRC differed between the production systems at depths $0-0.10$ and $0.10-0.20 \mathrm{~m}$ (Figure 1). The volumetric saturation soil water values $(\Theta s)$ were lower than $0.50 \mathrm{~m}^{3} \mathrm{~m}^{-3}$ showing a little reduction with the rise of the tension in all the ICLF. Marques (2002) noted that this tendency could be related to the greater volume of micropores and fewer macropores in the soil. This way, the macropores loss the retained water by capillarity at low tension, while the micropores retain the water until more negative potentials, providing more retention when in greatest proportions (Hillel, 1971). 


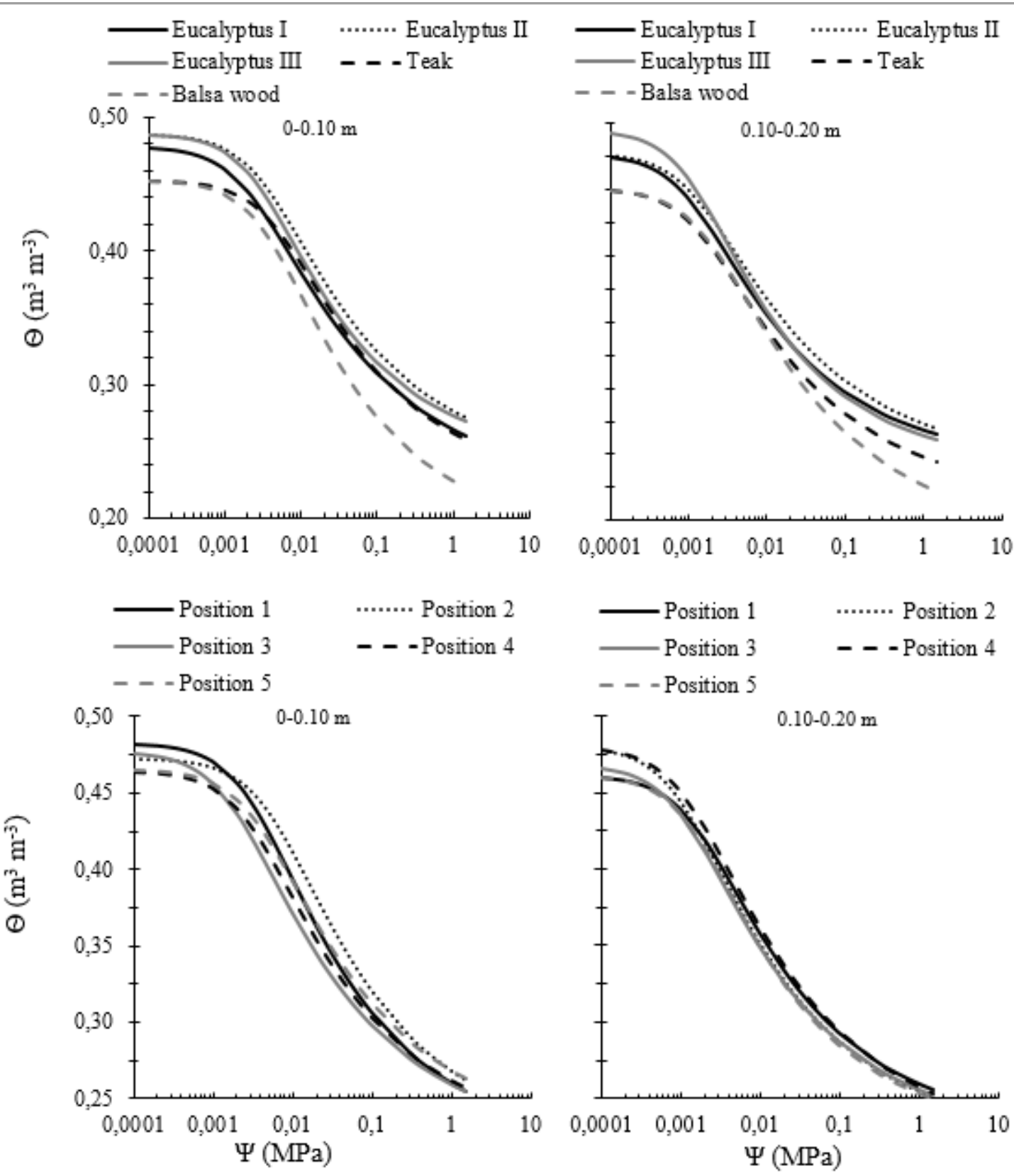

FIGURE 1. Water retention curves of Yellow Red Latosol in integrated systems with Eucalyptus, Balsa, and Teak by treatment and sampling position.

In the $0-0.10 \mathrm{~m}$ soil depth of Eucalyptus II and III showed higher values of $\Theta \mathrm{r}$ and $\Theta \mathrm{s}$, having bigger volumes of water in these systems (Table 2; Figure 1). The same behavior was observed in the $0.10-0.20 \mathrm{~m}$ layer, in the Eucalyptus I, not showing differences in the mean values between them. The Teak and Balsa wood showed the lowest values of $\Theta \mathrm{r}$ and $\Theta \mathrm{s}$, characterized by the fewer volumes of water content (Table 2; Figure 1).

The coefficients of the SWRC (Table 2; Figure 1) presented lower volume of soil water at FC and at WP in the Teak and Balsa wood, in both layers. So, independently of the field capacity and the wilting point, it is confirmed that although the ICLF are similar between the areas, the arrange of the forest species was enough to promote changings in the water retention at $\Psi$ of -0.01 and $-1.5 \mathrm{MPa}$ (Table 2).

The main changes in the hydro-physics properties of the forestry arrangements of ICLF with Teak and Balsa wood are due to the tree density (Assis et al., 2015). The
Teak and Balsa wood were arranged in a triple line $(3 \times 3$ x $3 \mathrm{~m}$ between tress) and with $20 \mathrm{~m}$ between rows with brachiaria. Throughout the 50 months of the experiment conduction, the trees of Teak and Balsa formed treetops big enough to reduce considerably the entry of sunlight into the system. That way, reducing the development of brachiaria, and consequently providing less soil protection. The poor development of brachiaria was associated with the footsteps of animals, also resulting in less physical protection of the soil in these systems.

According to Paciullo et al. (2008), the establishment of brachiaria under shadow presents phenotypic plasticity, as a response to the seasonal variations and to the shadow itself, with elevated potential for an ICLF. Meanwhile, it is necessary the thinning of the trees to reduce the grow of brachiaria. Andrade et al. (2009) guide the selection of the forage species to a species with a good productive capacity and tolerant to shadow and to the edaphoclimatic conditions. 
In relation only with the position of the sampling site, in the layer $0-0.10 \mathrm{~m}$ of depth, differences in the alpha coefficient of the SWRC were observed, being the highest value obtained in the P3 (Table 3; Figure 1). These results demonstrate a lower retention of water under the tree line in relation to the other sampled sites.

From the SWRC, it was possible to determine the volume of available water content (AWC), in the integrated systems, equivalent to the difference between the content of water retain at field capacity $(-0.01 \mathrm{MPa})$ and at wilting point (-1.5 $\mathrm{MPa}$ ) (Figures 2 and 3). The AWC is important to the root growth too, the chemical reactions, the movement and the absorption of nutrients for plants (Lepsch, 2011; Souza et al., 2016). The AWC was fewer in the systems Eucalyptus I, II and III in the layer of $0-0.10 \mathrm{~m}$, and greater in the areas with Balsa and Teak wood (Figure 2). This way, it is possible to observe that, even though the water retention was smaller, the water available is greater in these systems. Despite the systems Eucalyptus, I, II and III showed fewer AWC, these systems presenting wilting points close to $0.30 \mathrm{~m}^{3}$ $\mathrm{m}^{-3}$, indicating that it is possible to increase its AWC, with the structuration of the soil and the reducing the wilting point. Note that there were no significant differences in the AW values for the $0-0.10$ m layer, possibly due to this being the most exposed layer to the soil management.

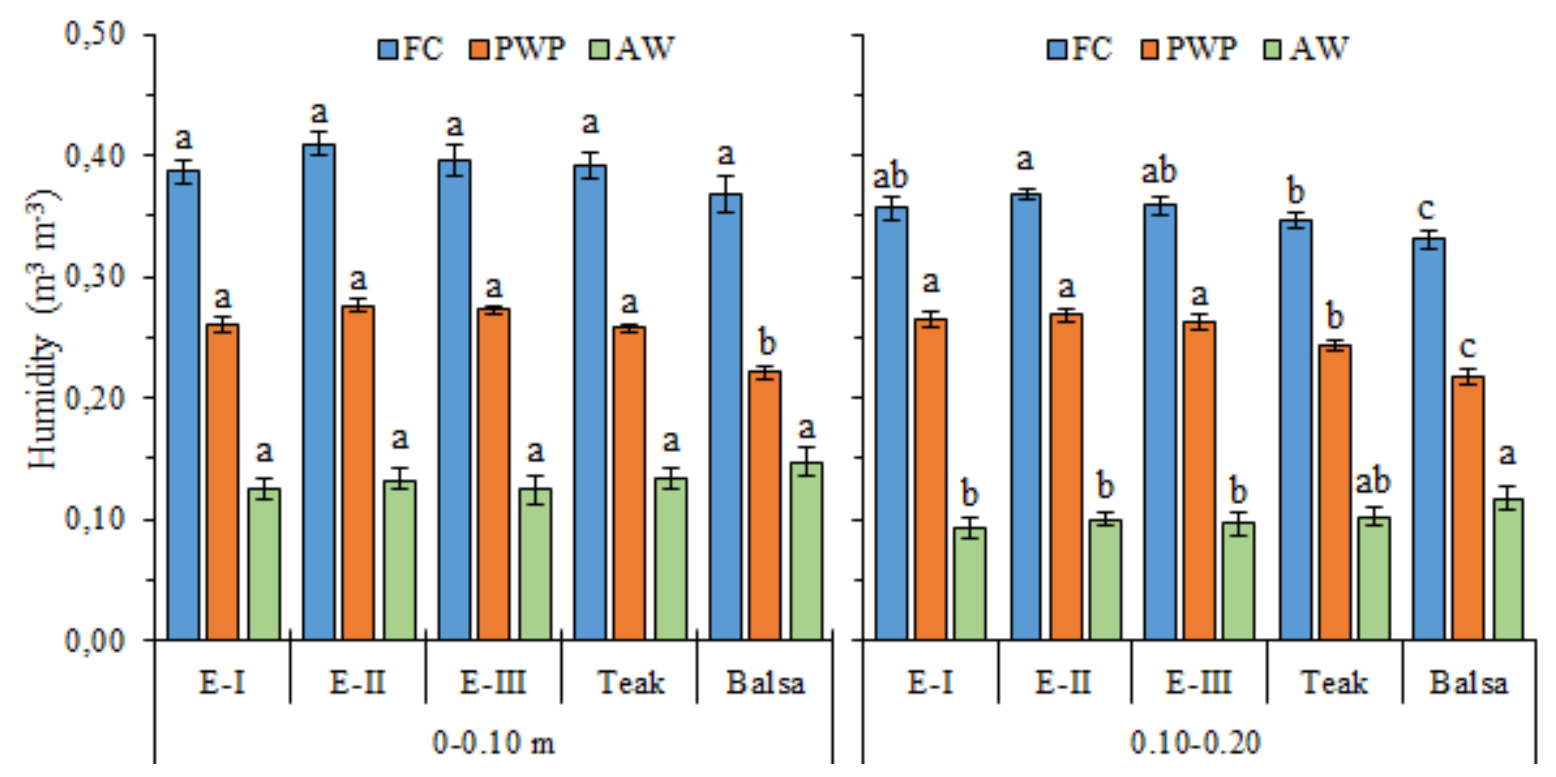

FIGURE 2. Field capacity (FC), permanent wilting point (PWP) and available water (AW) in layers 0-0.10 and 0.10-0.20 m referring to forest component arrangements with Eucalyptus, Teak, and Balsa wood in an integrated production system. E-I, Eucalyptus simple line; E-II, Eucalyptus double line; E-III, Eucalyptus triple line. The bars refer to the confidence interval of the means. Means followed by equal letters did not differ in the bootstrap test, at $5 \%$.

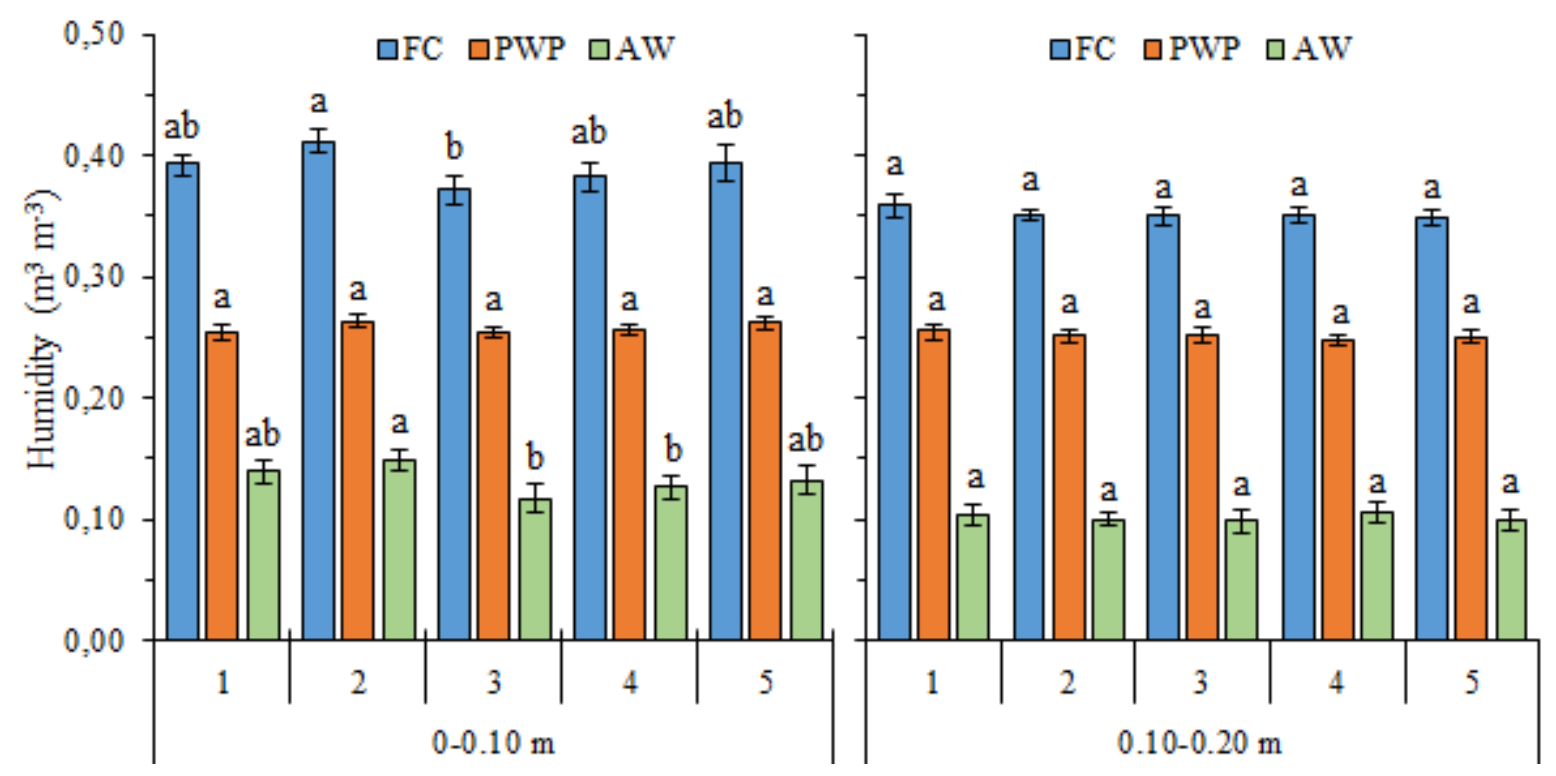

FIGURE 3. Field capacity (FC), permanent wilting point (PWP) and available water (AW) in layers $0-0.10$ and $0.10-0.20 \mathrm{~m}$ in integrated systems Eucalyptus I, II and III, Teak and Balsa wood depending on the sampling position. The bars refer to the confidence interval of the means. Means followed by equal letters did not differ in the bootstrap test, at $5 \%$. 
Under the sampling position P3, the lowest volume of water in the FC was verified, as well as for the volume of AW, which is the difference between the FC and PWP. Thus, changes in soil structural quality tend to be greater under the P3 sampling site based on the alpha attributes (Table 2; Figure 1), FC and AW at the 0-0.10 m layer (Figure 3).

The alterations observed in the P3 sampling position could have an indirect effect of the projection of treetops, providing more shadow during most of the daytime (Coelho et al., 2014), offering to the cattle better thermal conditions. That way, this position suffers more influence of the animal's footstep, having greater alterations on the soil structure (Moreira et al., 2012). The same phenomenon was observed by Souza Neto et al. (2014), which evaluated the soils physical attributes in ICLF, and identify that animals prefer areas under shadow, without quantifying the differences between areas with and without shadow.

Oliveira et al. (2007), evaluated the productive performance of brachiaria under different structural arrangements of ICLF, and reported less production of dry matter under treetops, independently of the arrangement.
The authors, attributes this behavior to the higher solar radiation incidence in the rows between trees, resulting in less hydric availability for the Eucalyptus and the brachiaria, and increasing the competition between crops, especially for water. This could also be verified with the SWRC between the sampling sites (Figure 1). The low vegetative development of the brachiaria associated to the trampling of the animals may have culminated in changes in the physical attributes of the soil under the tree line (position P3) in the layer $0-0.10 \mathrm{~m}$, leading to the lower water retention in this location.

Significant differences were observed for the $\mathrm{S}$ index between the ICLF systems in the 0-0.10 layer and $0.10-0.20 \mathrm{~m}$ layer (Figure 4). It was verified that the Teak ICLF system presented the lowest values being statistically different from the Eucalypt II and III systems in the $0-0.10 \mathrm{~m}$ layer and the Eucalypt III system in the $0.10-0.20 \mathrm{~m}$ layer. When comparing the sampling positions, there was a significant difference only in the 00.10 m layer. Sampling position P1 had the highest mean $S$ index (0.037), being different from positions 2 and 5 . There was no significant difference between the sampling positions P2, P3, P4, and P5.

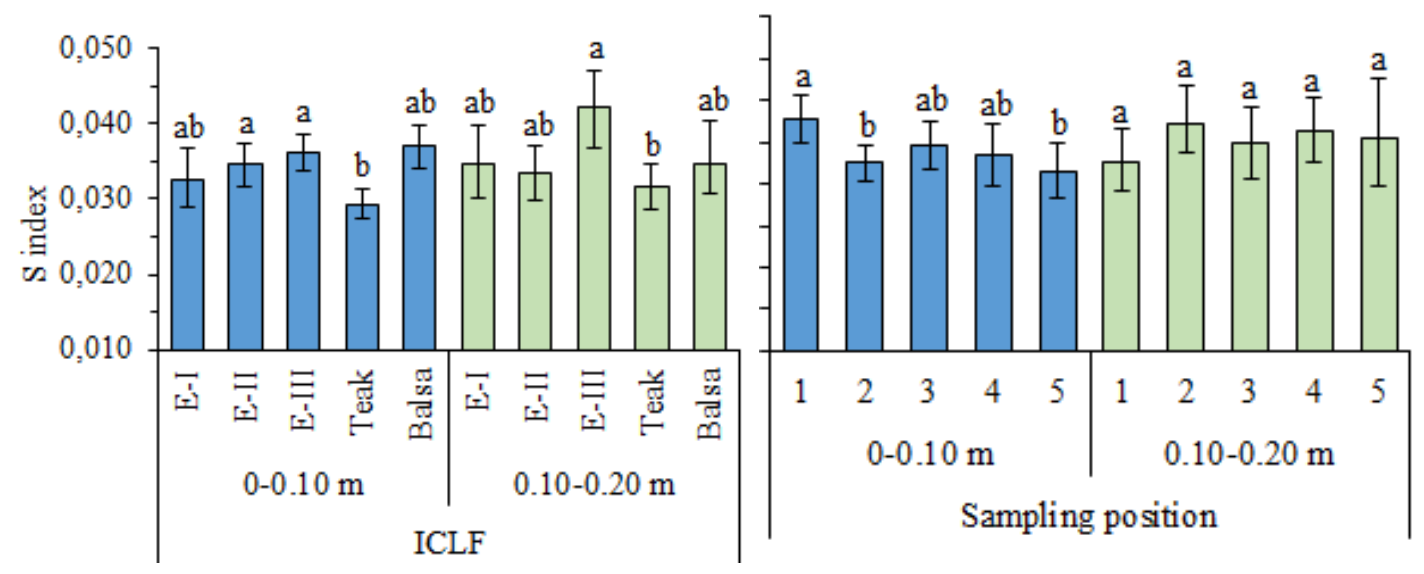

FIGURE 4. S index in layers 0-0.10 and 0.0-0.20 m referring to forest component arrangements and to five sampling points in an integrated production system. (E-I) Eucalyptus I, simple line; (E-II) Eucalyptus II, double line; (E-III) Eucalyptus III, triple line. The bars refer to the confidence interval of the means. Means followed by equal letters did not differ in the bootstrap test, at $5 \%$.

Dexter (2004a) evaluated that high $\mathrm{S}$ index values characterize soils with a strong presence of structural pores, representing good soils physical quality, and considering the value of 0.035 as the limit for the $\mathrm{S}$ index. Using this value as the separation between soils with degraded physical structure and soils with favorable conditions to the roots growth. With all, in function of the soils variability and the edaphoclimatic conditions, the physical limit determined by the $\mathrm{S}$ index could vary for each crop and region. Silva et al. (2010) point out that the $\mathrm{S}$ index values suggested by Dexter (2004a) are temporary as a source of soil physical quality classification.

Andrade \& Stone (2008), verified the adequacy of the $\mathrm{S}$ index as a diagnostic parameter of soils physical quality in "Cerrado", and suggested that soils with an S index higher than 0.045 show good structural quality. Soils with values lower than 0.045 tend to degradation. In this study, only P1 sampling site in the layer 0-0.10 showed values higher than 0.035 . The general mean value of the $\mathrm{S}$ index in the layer $0-0.10 \mathrm{~m}$ and $0.10-0.20 \mathrm{~m}$ was 0.34 and 0.035 , respectively. It can be observed that all the areas presented values of $\mathrm{S}$ index that characterize poor soil structural quality.

These low values of $\mathrm{S}$ index are possibly due to, the no soil disturbance in the areas with ICLF. In these systems, there were only made the opening of the rows for the planting of the forest species, with no mechanical preparation of soil (subsoiling or harrowing). That way, throughout the 50 months of experiment conduction, the integrated systems were not efficient to enhance the soils physical quality, based on the $\mathrm{S}$ index.

From the soil water retention curves, it was possible to analyze the distribution of the soil pores diameter (Klein \& Libardi, 2002), using the derivation of the equations related to the matric potential, as showed for the depths 00.10 and $0.10-0.20 \mathrm{~m}$ (Figure 5). Dexter (2004a) mentioned that low values of $\mathrm{S}$ index could be related to a diminution on the peak of frequency pores distribution, promoting a better inflection in the SWRC, in function of the reduction in the pores structural (Figure 5), and making more evident the low structural quality showed by the $S$ index, by the distribution of the soil pores sizes. 

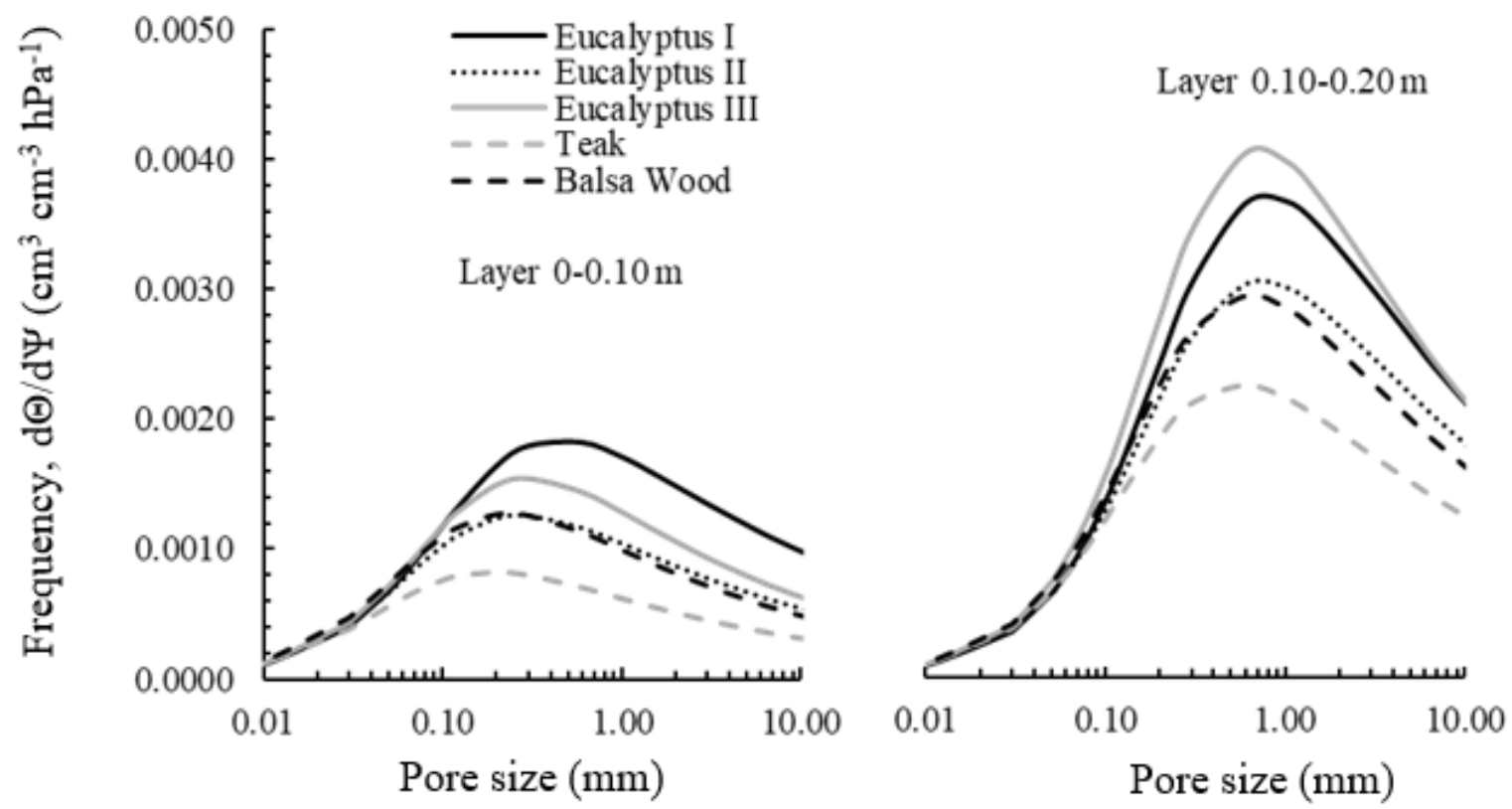

FIGURE 5. First derivative of the soil water retention curve $(d \Theta / d \Psi)$ as a function of the pore diameter (Øp) to layers of (a) 0-0.10 m and (b) $0.10-0.20 \mathrm{~m}$ of a Yellow Red Latosol submitted to crop-livestock-forest integration systems.

According to Klein (2014), the water retained in the pores with diameters lower than $0.0002 \mathrm{~mm}$ (criptopores) is unavailable for plants, because of the high energy in which is retained, meaning, above the WP. Therefore, it was observed that $47 \%$ of the water retained in the $0-0.10 \mathrm{~m}$ layer and $48 \%$ of the water retained in the 0.10-0.20 m layer was unavailable for plants. Silva \& Cabeda (2006) mentioned that the criptopores are not altered with soil mobilization. However, that it is necessary to adopt management practices that act in the soil structuration, aiming to increase the availability of water for plants.

The peaks of the maximum concentration of pores were found in the layers of $0.10-0.20 \mathrm{~m}$, explaining the vulnerability of the top layer $(0-0.10 \mathrm{~m})$, as a reason of agricultural management in this surface layer. A reduction of the total volume of pores was observed, without affecting the distribution of the soil pores diameter (Figure 5). This also explains better the behavior of the soil water retention in the Teak and Balsa wood treatments (Figure 1 and 5). Although the Eucalyptus I, II and III presented the greater soil water retention, they also presented lower volume of AWC, when compared with the Teak and Balsa wood treatments; this could be explained when observing the Figure 5. Even when there is a bigger frequency of pore near to $10 \mu \mathrm{m}$ of radius, part of them are criptopores (diameters smaller than $0.2 \mu \mathrm{m}$ ).

Based on the information obtained in this study, it is possible to consider that ICLF, as well as, the forest arrangement and the management, alters the soil structure. Meanwhile, it is necessary more investigation of the soils physical properties in these systems, because of the amount of factors involved, such as the forest arrangement, the density of the trees, the crops and the animal management. The site sampling position in the ICLF systems is fundamental for a more precise characterization (Assis et al., 2015), as shown in this study, where the soil water retention curve suffered alterations in the function of the forest rows.

\section{CONCLUSIONS}

The Crop-Livestock-Forestry Integration with forest arrangements having Eucalyptus promoting more content of water at the field capacity and in the wilting point, when compared to the Crop-Livestock- Forestry Integration having Teak and Balsa wood.

The Crop-Livestock-Forestry Integration having Teak and Balsa wood presented higher volumes of available water.

Although the Crop-Livestock-Forestry Integration with Eucalyptus showed less available water content, it also showed higher wilting point, demonstrating the potential to elevate the volume of available water content with soil structuration.

\section{ACKNOWLEDGEMENTS}

The authors would like to thanks to FAPEMAT (Fundação de Amparo à Pesquisa do Estado de Mato Grosso), for the financial support and the scholarship for the first author. Also to Embrapa Agrossilvipastoril and the Fazenda Gamada providing the area for this study.

\section{REFERENCES}

Andrade RS, Stone LF (2008) Índice S como indicador da qualidade física de solos do cerrado brasileiro. Revista Brasileira de Engenharia Agrícola e Ambiental 13(4):382388. DOI: http://dx.doi.org/10.1590/S141543662009000400003

Andrade RS, Stone LF, Silveira PM (2009) Culturas de cobertura e qualidade física de um Latossolo em plantio direto. Revista Brasileira de Engenharia Agrícola e Ambiental 13(4):411-418. DOI: http://dx.doi.org/10.1590/S1415-43662009000400007 
Assis PCR, Stone LF, Medeiros JC, Madari BE, Oliveira JM, Wruck FJ (2015) Atributos físicos do solo em sistemas de integração lavoura-pecuária-floresta. Revista Brasileira de Engenharia Agrícola e Ambiental 19(4):309316. DOI: http://dx.doi.org/10.1590/1807-

1929/agriambi.v19n4p309-316

Balbino LC, Cordeiro LAM, Oliveira P, Kluthcouski J, Galerani PR, Vilela L (2012) Agricultura sustentável por meio da integração lavoura-pecuária-floresta (iLPF). International Plant Nutrition Institute, p1-18. (Informações Agronômicas, 138).

Balbino LC, Cordeiro LAM, Porfírio-da-Silva V, Moraes A, Martínez GB, Alvarenga RC, Kichel NA, Fontaneli RS, Santos HP, Franchini JC, Galerani PR (2011) Evolução tecnológica e arranjos produtivos de sistemas de integração lavoura-pecuária-floresta no Brasil. Pesquisa Agropecuária Brasileira 46(10):1-12. DOI: http://dx.doi.org/10.1590/S0100-204X2011001000001

Barcellos AO, Medrado MJS, Grise MM, Skorupa LA, Rocha WSD (2011) Base conceitual, sistemas e benefícios da ILPF. In Balbino LC, Barcellos AO, Stone LF (eds). Marco referencial: integração lavoura-pecuária-floresta. Embrapa Informação Tecnológica, p23-37.

Carvalho R, Goedert WJ, Armando MS (2004) Atributos físicos da qualidade de um solo sob sistema agroflorestal. Pesquisa Agropecuária Brasileira 39(11):1153-1155. DOI: http://dx.doi.org/10.1590/S0100-204X2004001100015

Coelho JS, Araújo SAC, Viana MCM, Villela SDJ, Freire FM, Braz TGS (2014) Morfologia e valor nutritivo do campim-braquiária em sistema silvipastoril com diferentes arranjos espaciais. Semina: Ciências Agrárias 35(3):14871500. DOI: http://dx.doi.org/10.5433/1679-

0359.2014v35n3p1487

Christie D (2004) Resampling with Excel. Teaching Statistics, Medford 26(1):9-14. DOI:

http://dx.doi.org10.1111/j.1467-9639.2004.00136.x

Cunha EQ, Stone LF, Moreira JAA, Ferreira EPB, Didonet AD, Leandro WM (2011) Sistemas de preparo do solo e culturas de cobertura na produção orgânica de feijão e milho. Revista Brasileira de Ciência do Solo 35(2):589602. DOI: http://dx.doi.org/10.1590/S0100-

06832011000200029

Dexter AR (2004a) Soil physical quality g: Part I. Theory. Effects of soil texture, density, and organic matter, and effects on root growth. Geoderma 120:201-214. DOI: http://dx.doi.org/10.1016/j.geoderma.2003.09.004.

Dexter AR (2004b) Soil physical quality: Part II. Friabilty, tillage, filth and hard-setting. Geoderma 120:215-225. DOI: http://dx.doi.org/10.1016/j.geoderma.2003.09.005

Dexter AR (2004c) Soil physical quality: Part III. Unsaturated hydraulic conductivity and general conclusions about S-theory. Geoderma 120:227-239. DOI: http://dx.doi.org/10.1016/j.geoderma.2003.09.006
Dourado Neto D, Nielsen DR, Hopmans JW, Reichardt K, Bacchi OOS, Lopes PP (2001) Programa para confecção da curva de retenção de água no solo, modelo van Genuchten. Soil Water Retention Curve, SWRC (version 3,00 beta). Piracicaba, Universidade de São Paulo.

Efron B, Tibshirani RJ (1993) An introduction to the bootstrap. London, Chapman and Hall. 436p.

Fidalski J, Tormena CA, Alves SJ, Auler PAM (2013) Influência das frações de areia na retenção e disponibilidade de água em solos das formações Caiuá e Paranavaí. Revista Brasileira de Ciência do Solo 37(3):613-621. DOI: http://dx.doi.org/10.1590/S010006832013000300007

Hillel D (1971) Soil and Water. Physical principles and processes. New York, Academic Press. 288p.

Klein VA (2014) Física do solo. Passo Fundo, Universidade de Passo Fundo. 263p.

Klein VA, Libardi PL (2002) Densidade e distribuição do diâmetro dos poros de um Latossolo Vermelho, sob diferentes sistemas de uso e manejo. Revista Brasileira de Ciência do Solo 26(4):857-867. DOI:

http://dx.doi.org/10.1590/S0100-06832002000400003

Lepsch IF (2011) 19 lições de pedologia. São Paulo, Oficina de texto. p143-153.

Libardi PL (2010) Água no solo. In: van Lier QJ (ed). Física do solo. Sociedade Brasileira de Ciência do Solo, p103-150.

Lima HV, Silva AP, Giarola NFB, Imhoff S (2014) Index of soil physical quality of hardsetting soils on the Brasizilian coast. Revista Brasileira de Ciência do Solo 38(6):1722-1730. DOI: http://dx.doi.org/10.1590/S010006832014000600007

Machado JL, Tormena CA, Fidalski J, Scapim CA (2008) Inter-relações entre as propriedades físicas e os coeficientes da curva de retenção de água de um Latossolo sob diferentes sistemas de uso. Revista Brasileira de Ciência do Solo 32(2):495-502. DOI:

http://dx.doi.org/10.1590/S0100-06832008000200004

Marques JD, Libardi PL, van Lier QJ (2002) Relação entre horizontes pedológicos e propriedades hidráulicas em dois Latossolos. Revista Brasileira de Ciência do Solo 26(3):567-577. DOI: http://dx.doi.org/10.1590/S010006832002000300001

Mello JM, Couto EG, Amorin RSS, Johnson MS, LOBO FA (2015) Dinâmica dos atributos físico-químicos e variação sazonal dos estoques de carbono no solo em diferentes fitofisionomias do pantanal norte matogrossense. Revista Árvore 39(2):325-336. DOI: http://dx.doi.org/10.1590/0100-67622015000200012

Melo Filho JF, Libardi PL, van Lier QJ, Corrente JE (2002) Método convencional e "bootsptrap" para estimar o número de observações na determinação dos parâmetros da função $K(\Theta)$. Revista Brasileira de Ciência do Solo 26(4):895-903. DOI: http://dx.doi.org/10.1590/S010006832002000400006 
Melo Filho JF, Sacramento JAAS, Conceição BPS (2015) Curva de retenção elaborada pelo método do psicrômetro para uso na determinação do índice "s" de qualidade física do solo. Revista Engenharia Agrícola 35(5):959-966. DOI: http://dx.doi.org/10.1590/1809-4430-

Eng.Agric.v35n5p959-966/2015

Mendes MMS, Lacerda CF, Cavalcante ACR, Fernandes FEP, Oliveira TS (2013) Desenvolvimento do milho sob influência de arvores de pau-branco em sistema agrossilvipastoril. Pesquisa Agropecuária Brasileira 48(10):1342-1350. DOI: http://dx.doi.org/10.1590/S0100204X2013001000005

Moreira WH, Betioli Júnior E, Petean LP, Tormena CA, Alves SJ, Costa MAT, Franco HHS (2012) Atributos físicos de um Latossolo Vermelho distroférrico em sistemas de integração lavoura-pecuária. Revista Brasileira de Ciência do Solo 36(2):389-400. DOI:

http://dx.doi.org/10.1590/S0100-06832012000200008

Oliveira BS, Carvalho MAC, Lange A, Dallacort R, Silva VP (2015) Resistência do solo à penetração em áreas sob o sistema integração lavoura-pecuária-floresta, na região amazônica. Enciclopédia Biosfera 11(22):3678-3689. DOI: http://dx.doi.org/10.18677/Enciclopedia_Biosfera_2015_2 55

Oliveira TK, Macedo RLG, Santos IPA, Higashikawa EM, Venturin N (2007) Produtividade de Brachiaria brizantha (Hocht. ex. A. Rich) Stapf cv. Marandu sob diferentes arranjos estruturais de sistema agrossilvipastoril com eucalyptus. Ciência e Agrotecnologia 31(3):748-757. DOI: http://dx.doi.org/10.1590/S1413-70542007000300022

Paciullo DSC, Campos NR, Gomide CAM, Castro CRT, Tavela RC, Rossielo ROP (2008) Crescimento de capimbraquiária influenciado pelo grau de sombreamento e pela estação do ano. Pesquisa Agropecuária Brasileira 43(7):917-923. DOI: http://dx.doi.org/10.1590/S0100204X2008000700017

Pacheco AR, Chaves RQ, Nicoli CML (2013) Integration of crops, livestock, and forestry: a system of production for the Brazilian Cerrados. In: Hershey CH, Neate P (eds). Eco-efficiency: from vision to reality. CIAT, p51-61.

Paixão FJR, Andrade ARS, Azevedo CAV, Lima VLA, Dantas Neto J (2009) Uso da aproximação fractal no ajuste da curva de retenção de água no solo. Revista Brasileira de Engenharia Agrícola e Ambiental 13(3)282-288. DOI: http://dx.doi.org/10.1590/S1415-43662009000300009

Rosseti KV, Centurion JF, Souza Neto EL (2013) Physical quality of an oxisol after different periods of management systems. Revista Brasileira de Ciência do Solo 37(6):15221534. DOI: http://dx.doi.org/10.1590/S0100-

06832013000600009
Santos HG, Jacomine PKT, Anjos LHC, Lumbreras JF, Oliveira JB, Oliveira VA, Coelho MR, Almeida JA, Cunha TJF (2013) Proposta de atualização da segunda edição do Sistema Brasileiro de Classificação de Solos: ano 2013. Rio de Janeiro, Embrapa Solos, 2 ed.

Santos MV, Silva DV, Fonseca DM, Reis MR, Ferreira LR, Oliveira Neto SN, Oliveira FLR (2015) Componentes produtivos do milho sob diferentes manejos de plantas daninhas e arranjos de plantio em sistema agrossilvipastoril. Ciência Rural 45(9):1545-1550. DOI: http://dx.doi.org/10.1590/0103-8478cr20141224

Silva AP, Tormena CA, Dias Júnior MS, Imhoff S, Klein VA (2010) Indicadores da qualidade física do solo. In: van Lier QJ (ed). Física do solo. Viçosa, Sociedade Brasileira de Ciência do Solo, p241-281.

Silva AJN, Cabeda MSV (2006) Compactação e compressibilidade do solo sob sistemas de manejo e níveis de umidade. Revista Brasileira de Ciência do Solo 30(6):921-930. DOI: http://dx.doi.org/10.1590/S010006832006000600001

Silva BM, Oliveira GC, Serafim ME, Silva EA, Oliveira LM (2012) Índice S no diagnóstico da qualidade estrutural de Latossolo muito argiloso sob manejo intensivo.

Bioscience Journal 28(3):338-345.

Souza Neto EL, Andrioli I, Almeida RG, Macedo MCM, Lal R (2014) Physical quality of an Oxisol under an integrated crop-livestock-forest system in the Brazilian Cerrado. Revista Brasileira de Ciência do Solo 38(2):608618. DOI: http://dx.doi.org/10.1590/S010006832014000200025

Souza TMA, Souza TA, Souto LS, Sá FVS, Paiva EP, Mesquita EF (2016) Água disponível e cobertura do solo sob o crescimento inicial do feijão-caupi cv. BRS Pujante. Revista Brasileira de Agricultura Irrigada 10(3):598-604. DOI: http://dx.doi.org/10.7127/RBAI.V10N300345

van Genuchten MT (1980) A closed-form equation for predicting the hydraulic conductivity of unsaturated soils. Soil Science Society of America Journal 44(5):892-898. DOI:

http://dx.doi.org/10.2136/sssaj1980.036159950044000500 $02 \mathrm{x}$

van Genuchten MT, Nielsen DR (1985) On describing and predicting the hydraulic properties of unsatured soils. Annales Geophys 3(5):615-628, 1985.

WRB - World Reference Base for Soil Resources (2014) A framework for international classification, correlation and communication. FAO. (World Soil Resources Reports, 106). 